\title{
Spondylitis and Arthritis in Familial Mediterranean Fever
}

\author{
Ailesel Akdeniz Ateşinde Spondilit ve Artrit \\ Selda SARIKAYA, Şenay ÖZDOLAP, Erdem MARAŞLI \\ Department of Physical Medicine and Rehabilitation, Medical Faculty of Bülent Ecevit University, Zonguldak, Turkey
}

Objectives: This study aims to evaluate the clinical features of patients who are diagnosed with familial Mediterranean fever (FMF) and followed due to arthritis/spondylitis findings.

Patients and methods: The data of 29 patients (12 males, 17 females; mean age 26.1 \pm 11.2 years; range 16 to 51 years) who presented with arthritis and/or inflammatory spinal pain and were diagnosed with FMF between November 2000 and March 2012 were retrospectively analyzed. The age and gender of the patients were recorded. The age of onset of arthritis/spondylitis, age at FMF diagnosis, family history of FMF, and previous surgical history as well as the number of affected joints and their localization were also recorded. The presence of peripheral arthritis in patients with sacroiliitis and spondylitis was also investigated, and the drugs used for treatment were recorded. The results were documented in patients who underwent human leukocyte antigen (HLA)-B27 and Mediterranean fever (MEFV) gene analysis.

Results: The mean age of onset of arthritis/spondylitis was $20.4 \pm 9.1$ years. Arthritis was observed in 24 of the patients (monoathritis in 15 patients, oligoarthritis in 9 patients), and the most affected peripheral joint was the ankle $(n=13)$. Five patients had both arthritis and spondylitis while five others had only spondylitis. Four patients had a history of total hip replacement, one with knee debridement, and one with an appendectomy. The Mediterranean fever gene analysis was performed on 27 patients, and 10 of them (37\%) had a M694V homozygous mutation, and those who had undergone total hip replacement had the same mutation. The HLA-B27 gene analysis was performed on 21 patients, and two of them tested positive.

Conclusion: Familial Mediterranean fever should be included in the differential diagnosis of inflammatory arthritis and spondylitis in young patients. Classical arthritis attacks are the most common clinical presentation; however, chronic erosive joint involvement and spondylitis should be also recognized as clinical features of the disease. Although colchicine therapy is effective in preventing attacks and amyloidosis, both disease-modifying antirheumatic drugs (DMARDs) and biological drugs appear to be effective in treating severe forms of rheumatological disorders and chronic erosive arthritis.

Key words: Familial Mediterranean fever; spondylitis; colchicines; TNFalpha blockers.
Amaç: Bu çalışmada ailesel Akdeniz ateşi (AAA) tanısı olan ve artrit/spondilit bulgusu ile takip edilen hastaların klinik özellikleri incelendi.

Hastalar ve yöntemler: Kasım 2000 - Mart 2012 tarihleri arasında artrit veya inflamatuvar omurga ağrısı yakınması ile başvuran ve AAA tanısı konmuş 29 hastanın (12 erkek, 17 kadın; ort. yaş $26.1 \pm 11.2$ yıl; dağılım $16-51$ yıl) verileri retrospektif olarak incelendi. Hastaların yaş ve cinsiyetleri kaydedildi. Artrit/spondilit başlangıç yaşı, AAA tanı yaşı, ailede AAA öyküsü ve geçirilmiş cerrahi girişim öyküsü varlığının yanı sıra, periferik artriti bulunan hastaların tutulan eklem sayısı ve yeri de kaydedildi. Sakroiliit ve spondiliti bulunan hastalarda periferik artrit varlığı incelendi ve tedavide kullanılan ilaçlar kaydedildi. Insan lökosit antijen (HLA)-B27 ve Akdeniz ateşi (MEFV) geni analizi yapılmış hastaların sonuçları kaydedildi.

Bulgular: Artrit/spondilit başlangıç yaşı ortalama $20.4 \pm 9.1$ yıl idi. Hastaların 24'ünde artrit (15'inde monoartrit, 9'unda oligoartrit) mevcuttu ve en sık etkilenen periferik eklem, ayak bileği idi $(n=13)$. Beş hastada artritle birlikte spondilit, diğer beş hastada sadece spondilit mevcuttu. Dört hastada total kalça replasmanı, bir hastada diz debridmanı ve bir hastada apendektomi öyküsü vardı. Akdeniz ateşi geni analizi yapılan 27 hastanın 10'unda M694V homozigot mutasyonu (\%37) saptandı ve total kalça replasmanı cerrahisi geçiren hastaların tümünde aynı mutasyon vardı. HLA-B27 gen incelemesi yapılan 21 hastanın ikisinde HLAB27 pozitif idi.

Sonuç: Ailesel Akdeniz ateşi genç hastalarda inflamatuvar artrit ve spondilit ayırıcı tanısında mutlaka yer almalıdır. Klasik artrit atakları en sık görülen klinik tablo olsa da kronik eroziv eklem tutulumu ve spondilitin de bu hastalığın bir klinik görünümü olduğu akılda tutulmalıdır. Kolşisin tedavisi atakların ve amiloidozun önlenmesinde etkili olmakla birlikte, kronik eroziv artritlerde olduğu gibi romatolojik hastalıkların ağır formlarında kullanılan hastalık modifiye edici antiromatizmal ilaçlar (DMARD) ve biyolojik ilaçlar da etkin tedavi seçenekleri olarak görülmektedir.

Anahtar sözcükler: Ailesel Akdeniz ateşi; spondilit; kolşisin; TNF-alfa blokerleri. 
Familial Mediterranean fever (FMF) is an autoinflammatory, autosomal recessive disease characterized by self-limited fever and severe inflammatory attacks with an increased incidence in Eastern Mediterranean countries, particularly Turkey ${ }^{[1,2]}$ Evidence has indicated that FMF is associated with the Mediterranean fever (MEFV) gene localized at the $16^{\text {th }}$ chromosome and the mutations on that gene that cause clinical symptoms. ${ }^{[3,4]}$ A wide spectrum of musculoskeletal signs and symptoms are present in FMF, including arthralgia, arthritis, entesitis, and sacroiliitis. Peripheral arthritis is common, whereas spondylitis is seen in only $2-3 \%$ of cases. This study discusses the clinical features of patients diagnosed with FMF who also have symptoms of arthritis and spondylitis.

\section{PATIENTS AND METHODS}

Twenty-nine patients (12 males, 17 females; mean age $26.2 \pm 11.2$ years; range 16 to 51 years) that presented with arthritis and/or inflammatory spinal pain and were diagnosed with FMF between November 2000 and March 2012 were retrospectively analyzed. The previous FMF diagnosis was reviewed for all patients using the Tel Hashomer criteria. ${ }^{[5]}$ The ages and genders of the patients were recorded along with information about age at onset of arthritis/ spondylitis, age at FMF diagnosis, family history of FMF, and previous surgical history. In addition, the number of affected joints and their localization were also determined for each patient. The presence of peripheral arthritis in patients with sacroiliitis and spondylitis was also investigated, and the medications of the patients were noted. Some patients were included in a human leukocyte antigen (HLA)-B27 and MEFV gene analysis, and their results were recorded, too.

\begin{tabular}{|c|c|c|c|}
\hline & $\begin{array}{c}\text { Joint } \\
\text { number }\end{array}$ & Joint & $\begin{array}{c}\text { Number of } \\
\text { patients }\end{array}$ \\
\hline \multirow[t]{11}{*}{ Arthritis } & 1 & Ankle & 8 \\
\hline & & Knee & 2 \\
\hline & & Hip & 2 \\
\hline & & Hands/feet & 2 \\
\hline & & Shoulder & 1 \\
\hline & 2 & Knee/ankle & 2 \\
\hline & & Knee/wrist & 1 \\
\hline & & Hip/knee & 1 \\
\hline & & Hands/feet & 2 \\
\hline & 3 & Hip/knee/ankle & 2 \\
\hline & & Knee/ankle/hands & 1 \\
\hline Total & & & 24 \\
\hline
\end{tabular}

The Ethics Committee of our university approved our research.

\section{RESULTS}

The mean age are onset of arthritis/spondylitis for the study participants was $20.4 \pm 9.1$ years. Seven patients had a family history of FMF. In 13 patients (44.8\%), fever coincided with arthritis/spondylitis; however, peritonitis coincided with arthritis/spondylitis in 20 (69\%) patients, and pleuritis in six others (20.7\%). Their medical history indicated that four patients had undergone total hip replacements, one patient had had a knee debridement, and one had undergone an appendectomy. Arthritis was observed in 24 of the patients, with 15 having monoarthritis and nine having oligoarthritis. The ankle joint was the most affected joint $(n=13)$. This was followed by the knee $(n=9)$, hip and small joints of the hands $(n=5)$, and small joints of the feet $(n=4)$ (Table 1). Five patients had both arthritis and spondylitis while five others had only spondylitis. The information regarding the patients with spondylitis is summarized in Table 2, and the radiographs of the patients with spondylitis are shown in Figure 1. An analysis of the MEFV gene was performed on 27 patients, and the M696V mutation was the one that was most frequently seen (Table 3). All patients with a history of total hip replacement had the M694V homozygous mutation (Figure 2). Additionally, an analysis of the HLA-B27 gene was conducted on 21 patients, and two tested positive. Because the patients with spondylitis fulfilled the criteria for FMF and ankylosing spondylitis (AS), we regarded them as having both. One of these patients had spondylitis while another had only ankle arthralgia and arthritis which was localized in the toe. Almost all of the patients had colchicine therapy, but they were also administered different medications such as nonsteroidal anti-inflammatory drugs (NSAIDs), disease-modifying antirheumatic drugs (DMARDs), and anti-tumor necrosis factor (anti-TNF) agents according to the presence of either peripheral arthritis or spondylitis (Table 4). In reviewing the medical records of the patients, two had amyloidosis proven by a renal biopsy. The others had normal renal function tests.

\section{DISCUSSION}

Articular involvement is one of the most common and significant features of FMF. Arthritis usually occurs during recurrences, which can be short-term and self-limiting in nature. ${ }^{[6,7]}$ Monoarthritis occurs 


\begin{tabular}{|c|c|c|c|c|c|}
\hline No & Age/gender & Arthritis & HLA-B27 & MEFV gene mutation & Medication \\
\hline \multirow[t]{2}{*}{1} & $35 / \mathrm{M}$ & + & $?$ & ? & Colchicine $0.5 \mathrm{mg} /$ day \\
\hline & & & & & Adalimumab $40 \mathrm{mg} / 2$ weeks \\
\hline \multirow[t]{2}{*}{2} & $17 / \mathrm{F}$ & + & + & M694V/- & Sulphasalazine $2 \mathrm{~g} /$ day \\
\hline & & & & & Colchicine $0.5 \mathrm{mg} /$ day \\
\hline \multirow[t]{2}{*}{3} & $42 / \mathrm{M}$ & + & - & M694V/M694V & Sulphasalazine 2 g/day \\
\hline & & & & & Colchicine $0.5 \mathrm{mg} /$ day \\
\hline \multirow[t]{2}{*}{4} & $30 / \mathrm{M}$ & + & - & M694V/M694V & Colchicine $0.5 \mathrm{mg} /$ day \\
\hline & & & & & Etanercept $50 \mathrm{mg} /$ week \\
\hline \multirow[t]{2}{*}{5} & $34 / \mathrm{F}$ & - & $?$ & M694V/M694V & Colchicine $1.5 \mathrm{mg} /$ day \\
\hline & & & & & Infliximab $5 \mathrm{mg} / \mathrm{kg} / 8$ weeks \\
\hline 6 & $22 / \mathrm{F}$ & - & - & E148Q/- & Indomethacin $100 \mathrm{mg} /$ day \\
\hline \multirow[t]{2}{*}{7} & $51 / \mathrm{M}$ & - & - & M694V/M680I & Colchicine $0.5 \mathrm{mg} /$ day \\
\hline & & & & & Adalimumab $40 \mathrm{mg} / 2$ weeks \\
\hline \multirow[t]{2}{*}{8} & $23 / \mathrm{F}$ & - & - & E148Q/- & Sulphasalazine $2 \mathrm{~g} /$ day \\
\hline & & & & & Colchicine $0.5 \mathrm{mg} /$ day \\
\hline \multirow[t]{2}{*}{9} & $18 / \mathrm{F}$ & + & ? & M694V/M694V & Colchicine $1.5 \mathrm{mg} /$ day \\
\hline & & & & & Adalimumab $40 \mathrm{mg} / 2$ weeks \\
\hline 10 & $48 / \mathrm{M}$ & - & $?$ & V726A/- & Indomethacin $100 \mathrm{mg} / \mathrm{day}$ \\
\hline
\end{tabular}

where the large joints of the lower extremities are involved. ${ }^{[7]}$ Sometimes arthritis is the first symptom of FMF, and occasionally it is the only symptom present. ${ }^{[8]}$ In 2005, a Turkish FMF study group reported that the co-occurrence of arthritis with FMF was $47.7 \%{ }^{[9]}$ In our study group, patients consulted their physicians because of pain and swelling in the extremities, and $82.8 \%$ of patients had arthritis while $17.2 \%$ had both spondylitis and arthritis. In these patients, the arthritis was confined mostly to the lower extremities. In FMF, arthritis is most often seen in the ankles and knees, and ankle involvement was also the most common location in our patients.

The MEFV gene is localized at the lesser arm of the $16^{\text {th }}$ chromosome, and mutations in this gene have been reported. ${ }^{[10,11]}$ The most frequent mutations in Turkey
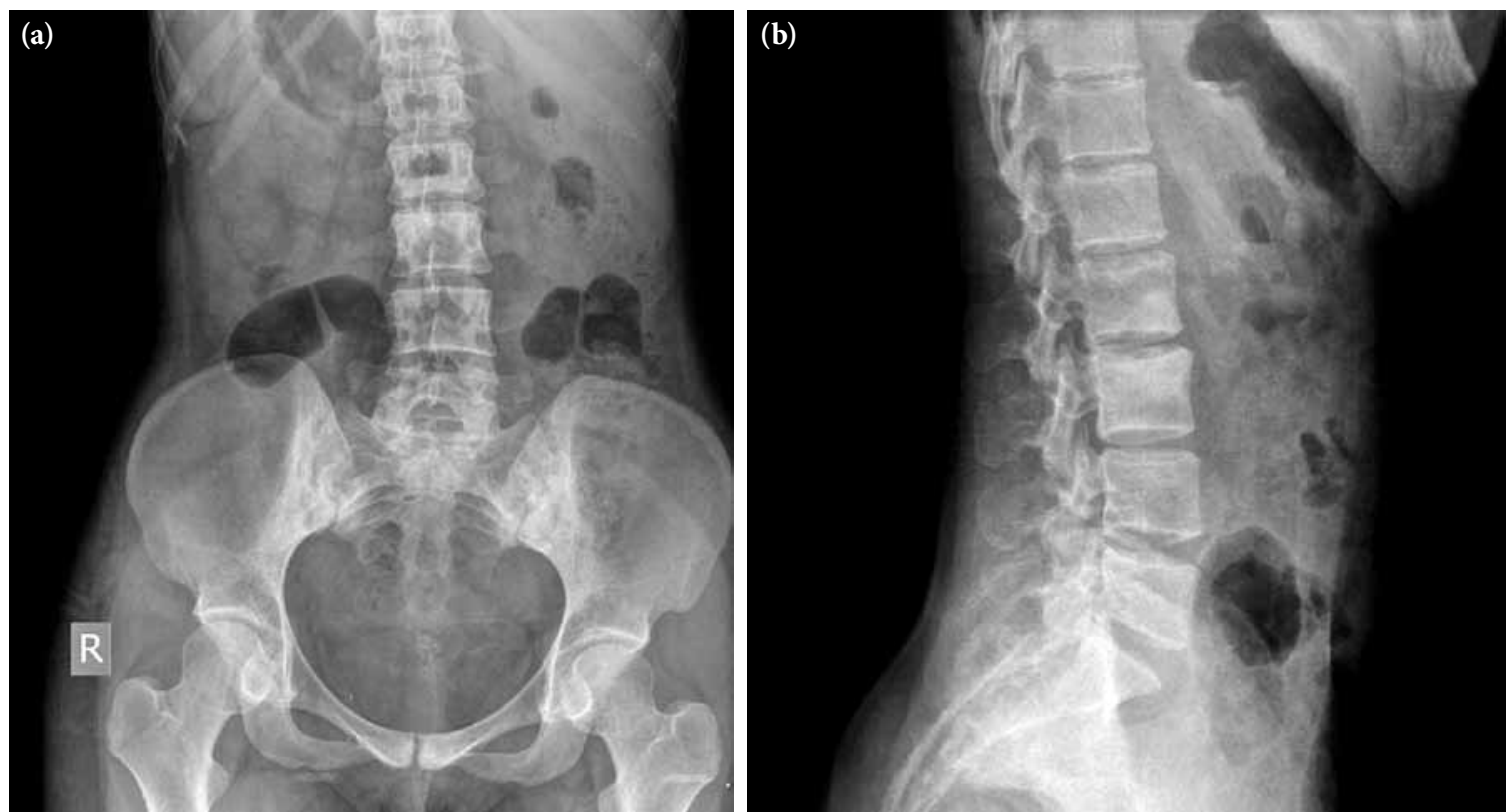

Figure 1. Polyacryl amide gel and lateral lumbar radiographs of the patient with M694V homozygous mutation in Mediterranean fever gene analysis. (a) Bilateral stage III sacroiliitis. (b) Square-shaped alterations at the lumbar vertebrae and sacroiliitis. 


\begin{tabular}{|lc|}
\hline \multicolumn{2}{c|}{ Table 3. Mediterranean fever gene analysis of the patients } \\
\hline MEFV gene mutation (n) & Number of patients \\
\hline Homozygous (12) & 10 \\
M694V/M694V & 1 \\
E148Q/E148Q & 1 \\
M680I/M680I & \\
Compound heterozygous (4) & 2 \\
M694V/E148Q & 1 \\
M694V/M680I & 1 \\
M694V/V726A & \\
Heterozygous (11) & 5 \\
E148Q/- & 3 \\
M694V/- & 3 \\
V726A/- & 27 \\
Total & \\
MEFV gene: Mediterranean fever gene. & \\
\hline
\end{tabular}

include M694V, M680I, V726A, E148Q, and M694I. ${ }^{[9]}$ Similar to our study, most clinical trials in Turkey have reported the M694V mutation as "the most common mutation". ${ }^{[9,12-14]}$ In the literature, there is evidence that has addressed the association between the M694V mutation and early onset, frequent arthritis, and the high incidence of amyloidosis..$^{[9,15-18]}$ In our study, patients with the homozygous M694V mutation had more polyarticular involvement; moreover, all patients with joint replacement surgery due to destructive hip arthritis had this mutation. These findings support the literature. In a review involving a Turkish FMF study group, it was estimated that only $5 \%$ of all FMF cases were included in their study. Furthermore, there were patients who were never diagnosed. ${ }^{[9]}$ This study group included most university hospitals and other reference hospitals, and it was reported that the majority of the patients had never been diagnosed or that their clinical symptoms had been too insignificant to be identified.
However, it should be noted that only rheumatology units were included in the study and that most patients with arthritis or spondylitis consult with physical medicine and rehabilitation clinics or orthopedic departments. To determine exact data with regard to Turkish FMF, cases that have been investigated for arthritis symptoms and been diagnosed with FMF should be included in future studies. In particular, monoarthritis cases might be misdiagnosed because articular aspiration reveals high leukocyte counts, and these patients are often treated medically and surgically as if they have septic arthritis. In fact, sometimes these cases may indeed resemble septic arthritis in imaging modalities. ${ }^{[19]}$ Similar to other cases that have been reported in the literature, ${ }^{[19,20]}$ one of ours was misdiagnosed as having septic arthritis, and arthroscopic irrigation and debridement were performed due to the septic arthritis pre-diagnosis. This patient was revealed to have been suffering from acute fever and arthritic episodes ever since childhood, and the family history was positive for FMF. It was revealed that the patient had been administered various medications due to the rheumatoid arthritis (RA) misdiagnosis since the age of 12 . Colchicine treatment relieved this patient's pain and fever, and our institution followed up the patient.

Acute arthritis is typical for FMF; however, prolonged arthritis may be observed as well. Joint inflammation usually is reduced over a two-week period, but synovial effusion persists. In addition, these patients do not have a fever. The most commonly affected joints are the knee and hip joints. However, the destructive process is not observed in the knee but in the hip joint. ${ }^{[21,22]}$ One of our cases had bilateral prolonged knee arthritis. This patient had been followed up as an
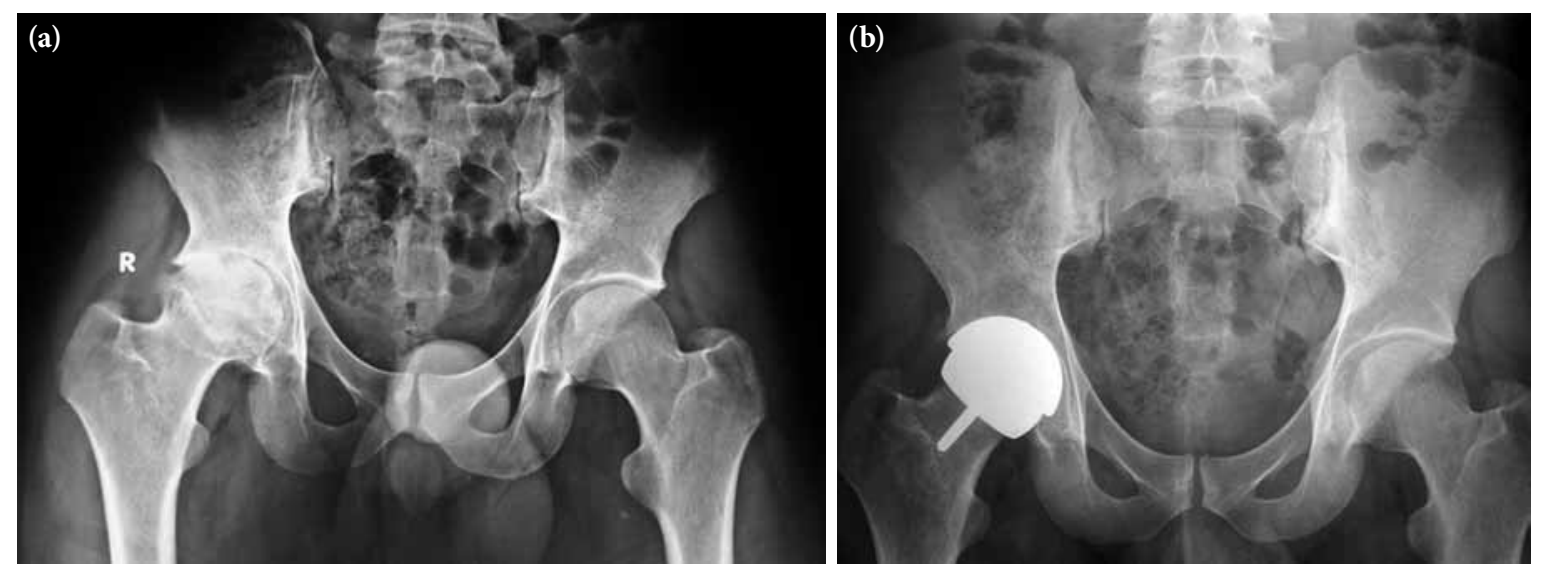

Figure 2. A 30-year-old patient with M694V homozygous mutation in Mediterranean fever gene analysis. (a) Destructive changes at the right hip joint due to prolonged arthritis. (b) Radiograph after total endoprosthetic operation. 


\begin{tabular}{|lc|}
\hline Table 4. Patients' medical treatment & \\
\hline Medication & Number of patients \\
\hline Colchicine $(0.5-2 \mathrm{mg} /$ day) & 26 \\
Sulphasalazine (2 g/day) & 6 \\
& 3 (Spondylitis) \\
& 3 (Arthritis) \\
Anti-TNF & 7 \\
& 5 (Spondylitis) \\
& 2 (Arthritis) \\
Methotrexate (15 mg/week) & 1 \\
NSAIDs & 6 \\
Corticosteroids (10 mg/day) & 2 \\
\hline TNF: Tumor necrosis factor; NSAIDs: Nonsteroidal anti-inflammatory drugs. \\
\hline
\end{tabular}

RA patient, but the diagnosis was reinvestigated due to the absence of RA serology, juvenile onset, and the lack of response to the current DMARD therapies. A gene analysis revealed that the MEFV had a V726A heterozygous mutation, and colchicine was then added to the therapy. Unfortunately, this therapy failed as well, and anti-TNF therapy was prescribed. However, due to pregnancy, the therapy was not administered.

Spondylitis is one of the musculoskeletal involvements of FMF. Kaşifoğlu et al. ${ }^{[12]}$ reported that $7 \%$ of FMF patients had sacroiliitis. However, when patients with only musculoskeletal complaints were added to the analysis, $32.7 \%$ of them had this inflammatory condition. Different imaging methods for sacroiliitis have provided different results in the literature. ${ }^{[23,24]}$ It is a general consensus that spondyloarthropathy in FMF cases is negative for HLA-B27 and that spinal ankylosis is also absent. ${ }^{[5]}$ Patients who are positive for HLA-B27 and who have spinal ankylosis are considered to have FMF that coincides with AS. ${ }^{[25,26]}$ We found that $34.5 \%$ of our cases had spondylitis, but only one of these patients tested positive for HLA-B27. Therefore, this patient was considered to have both FMF and AS. We found that the most common mutation in these patients was M694V. Similarly, Kaşifoğlu et al. ${ }^{[12]}$ reported that the M694V mutation was more common than other mutations.

There is increasing interest regarding FMF in conjunction with spondyloarthropathies, as some studies have suggested that the MEFV mutation is increased in AS patients. ${ }^{[26-31]}$ Çınar et al. ${ }^{[28]}$ found that $30.5 \%$ of AS patients had at least one MEFV gene mutation. Conversely, some studies have suggested that there is no difference between AS cases and the general population. ${ }^{[30]}$ Some authors have even proposed that
FMF may be classified in the spondyloarthropathy spectrum. ${ }^{[32]}$ Çinar et al. ${ }^{[28]}$ suggested that the use of colchicine treatment in AS patients who have the MEFV gene mutation may provide advantages in the areas of anti-inflammation and amyloidosis. ${ }^{[28]}$

Colchicine is the primary choice of treatment because it is known to suppress acute episodes and prevent amyloidosis, ${ }^{[33-35]}$ but some cases have been reported that did not respond to this therapy. For patients who do not respond to colchicine, there is no consensus for their treatment. Recent studies have reported that tumor necrosis factor-alpha (TNF- $\alpha$ ) plays an important role in various inflammatory processes, and serum TNF- $\alpha$ levels of FMF patients have been reduced with continuous colchicine therapy. ${ }^{[36]}$ The pathogenesis of TNF- $\alpha$ in FMF is not clear, but recent studies have reported that antiTNF- $\alpha$ therapies have decreased attacks in FMF patients. ${ }^{[37,38]}$ Eight of our patients were administered anti-TNF- $\alpha$ therapy, and one had both FMF and AS.

Despite expectations, it was discovered that most of the cases of FMF seen in Turkey are not in Mediterranean regions but in inner Anatolia, east Anatolia, and the eastern Black Sea area. Nevertheless, physicians should still consider FMF as a differential diagnosis when treating a patient with arthritis. A thorough investigation of patients may uncover many undiagnosed subjects. Even an MEFV gene analysis may help in the diagnosis of FMF since it has a high carrier rate in Turkey. However, this analysis is only useful when it is evaluated together with clinical and laboratory findings. Early diagnosis and treatment is vital not only for arthritis, but also for amyloidosis.

In conclusion, Familial Mediterranean fever has an earlier onset when compared to other rheumatologic disorders, with approximately five years existing between the onset of symptoms and diagnosis. Therefore, in patients with peripheral arthritis and spondylitis, FMF should be considered as a differential diagnosis, and other signs and symptoms of the disease should be investigated. An analysis for the MEFV gene might also be helpful in suspicious cases.

\section{Declaration of conflicting interests}

The authors declared no conflicts of interest with respect to the authorship and/or publication of this article.

\section{Funding}

The authors received no financial support for the research and/or authorship of this article. 


\section{REFERENCES}

1. Booth DR, Lachmann HJ, Gillmore JD, Booth SE, Hawkins PN. Prevalence and significance of the familial Mediterranean fever gene mutation encoding pyrin Q148. QJM 2001;94:527-31.

2. Samuels J, Aksentijevich I, Torosyan Y, Centola M, Deng Z, Sood R, et al. Familial Mediterranean fever at the millennium. Clinical spectrum, ancient mutations, and a survey of 100 American referrals to the National Institutes of Health. Medicine (Baltimore) 1998;77:268-97.

3. Cazeneuve C, Dode C, Delpech M, Touitou I, Grateau G, Amselem S. French Society for Human Genetics. "Genetics in Practice" Commission. Core scientific data of use in genetic counseling. Familial Mediterranean fever. Ann Genet 1999;42:241-5. [Abstract]

4. Pras E, Aksentijevich I, Levy E, Gruberg L, Prosen L, Dean $M$, et al. The gene causing familial Mediterranean fever maps to the short arm of chromosome 16 in Druze and Moslem Arab families. Hum Genet 1994;94:576-7.

5. Langevitz P, Livneh A, Zemer D, Shemer J, Pras M. Seronegative spondyloarthropathy in familial Mediterranean fever. Semin Arthritis Rheum 1997;27:67-72.

6. Garcia-Gonzalez A, Weisman MH. The arthritis of familial Mediterranean fever. Semin Arthritis Rheum 1992;22:139-50.

7. Ince E, Cakar N, Tekin M, Kendirli T, Ozkaya N, Akar N, et al. Arthritis in children with familial Mediterranean fever. Rheumatol Int 2002;21:213-7.

8. Lidar M, Kedem R, Mor A, Levartovsky D, Langevitz P, Livneh A. Arthritis as the sole episodic manifestation of familial Mediterranean fever. J Rheumatol 2005;32:859-62.

9. Tunca M, Akar S, Onen F, Ozdogan H, Kasapcopur O, Yalcinkaya F, et al. Familial Mediterranean fever (FMF) in Turkey: results of a nationwide multicenter study. Medicine (Baltimore) 2005;84:1-11.

10. Ancient missense mutations in a new member of the RoRet gene family are likely to cause familial Mediterranean fever. The International FMF Consortium. Cell 1997;90:797-807.

11. Gershoni-Baruch R, Brik R, Zacks N, Shinawi M, Lidar $\mathrm{M}$, Livneh A. The contribution of genotypes at the MEFV and SAA1 loci to amyloidosis and disease severity in patients with familial Mediterranean fever. Arthritis Rheum 2003;48:1149-55.

12. Kaşifoğlu T, Calişir C, Cansu DU, Korkmaz C. The frequency of sacroiliitis in familial Mediterranean fever and the role of HLA-B27 and MEFV mutations in the development of sacroiliitis. Clin Rheumatol 2009;28:41-6.

13. Onen F. Familial Mediterranean fever. Rheumatol Int 2006;26:489-96.

14. Sayarlioglu M, Cefle A, Inanc M, Kamali S, Dalkilic E, Gul A, et al. Characteristics of patients with adult-onset familial Mediterranean fever in Turkey: analysis of 401 cases. Int J Clin Pract 2005;59:202-5.

15. Brik R, Shinawi M, Kepten I, Berant M, Gershoni-Baruch R. Familial Mediterranean fever: clinical and genetic characterization in a mixed pediatric population of Jewish and Arab patients. Pediatrics 1999;103:e70.
16. Cazeneuve C, Sarkisian T, Pêcheux C, Dervichian M, Nédelec B, Reinert $\mathrm{P}$, et al. MEFV-Gene analysis in armenian patients with Familial Mediterranean fever: diagnostic value and unfavorable renal prognosis of the M694V homozygous genotype-genetic and therapeutic implications. Am J Hum Genet 1999;65:88-97.

17. Livneh A, Langevitz P, Shinar Y, Zaks N, Kastner DL, Pras $\mathrm{M}$, et al. MEFV mutation analysis in patients suffering from amyloidosis of familial Mediterranean fever. Amyloid 1999;6:1-6.

18. Mansour I, Delague V, Cazeneuve C, Dodé C, Chouery E, Pêcheux C, et al. Familial Mediterranean fever in Lebanon: mutation spectrum, evidence for cases in Maronites, Greek orthodoxes, Greek catholics, Syriacs and Chiites and for an association between amyloidosis and M694V and M694I mutations. Eur J Hum Genet 2001;9:51-5.

19. Uthman I, El-Sayyad J, El-hajj I, Bizri AR. Familial Mediterranean fever mimicking septic arthritis. Rheumatol Int 2005;25:633-4.

20. Usluer H, Bircan Z. Protracted familial mediterranean fever arthritis presenting as septic arthritis. Rheumatol Int 2007;27:1083-5.

21. Jarjour RA, Dodaki R. Arthritis patterns in familial Mediterranean fever patients and association with M694V mutation. Mol Biol Rep 2011;38:2033-6.

22. Younes M, Kahn MF, Meyer O. Hip involvement in patients with familial Mediterranean fever. A review of ten cases. Joint Bone Spine 2002;69:560-5.

23. Cefle A, Kamali S, Sayarlioglu M, Inanc M, Ocal L, Aral $\mathrm{O}$, et al. A comparison of clinical findings of familial Mediterranean fever patients with and without amyloidosis. Rheumatol Int 2005;25:442-6.

24. Yildiz M, Tunc SE, Sahin M, Okudan B, Aydin O, Suslu $\mathrm{H}$, et al. Evaluation of joints using Tc 99m-MDP bone scintigraphy in patients with familial Mediterranean fever: should bone scans be used for diagnosis and followup? Rheumatol Int 2006;26:220-3.

25. Keleş I, Aydin G, Tosun A, Inal E, Keleş H, Orkun S. Familial Mediterranean fever and ankylosing spondylitis in a patient with juvenile idiopathic arthritis: A case report and review of the literature. Rheumatol Int 2006;26:846-51.

26. Ozdolap S, Sarikaya S, Aktunc E. Familial Mediterranean fever and ankylosing spondylitis. Romatizma 2006;21:31-3.

27. Akkoc N, Sari I, Akar S, Binicier O, Thomas MG, Weale $\mathrm{ME}$, et al. Increased prevalence of $\mathrm{M} 694 \mathrm{~V}$ in patients with ankylosing spondylitis: additional evidence for a link with familial mediterranean fever. Arthritis Rheum 2010;62:3059-63.

28. Cinar M, Dinc A, Simsek I, Erdem H, Koc B, Pay S, et al. The rate and significance of Mediterranean fever gene mutations in patients with ankylosing spondylitis: a three-month, longitudinal clinical study. Rheumatol Int 2008;29:37-42.

29. Cosan F, Ustek D, Oku B, Duymaz-Tozkir J, Cakiris A, Abaci N, et al. Association of familial Mediterranean feverrelated MEFV variations with ankylosing spondylitis. Arthritis Rheum 2010;62:3232-6. doi: 10.1002/art.27683. 
30. Durmus D, Alayli G, Cengiz K, Yigit S, Canturk F, Bagci $\mathrm{H}$. Clinical significance of MEFV mutations in ankylosing spondylitis. Joint Bone Spine 2009;76:260-4.

31. Incel NA, Saraçoğlu M, Erdem HR. Seronegative spondyloarthropathy of familial Mediterranean fever. Rheumatol Int 2003;23:41-3.

32. Rabinovitch E, Harats D, Yaron P, Luvish T, Lidar M, Kedem R, et al. Familial Mediterranean fever gene and protection against asthma. Ann Allergy Asthma Immunol 2007;99:517-21.

33. Goldfinger SE. Colchicine for familial Mediterranean fever. N Engl J Med 1972;287:1302.

34. Livneh A, Zemer D, Langevitz P, Laor A, Sohar E, Pras M. Colchicine treatment of AA amyloidosis of familial Mediterranean fever. An analysis of factors affecting outcome. Arthritis Rheum 1994;37:1804-11.
35. Livneh A, Zemer D, Siegal B, Laor A, Sohar E, Pras M. Colchicine prevents kidney transplant amyloidosis in familial Mediterranean fever. Nephron 1992;60:418-22.

36. Kiraz S, Ertenli I, Arici M, Calgüneri M, Haznedaroglu I, Celik I, et al. Effects of colchicine on inflammatory cytokines and selectins in familial Mediterranean fever. Clin Exp Rheumatol 1998;16:721-4.

37. Bilgen SA, Kilic L, Akdogan A, Kiraz S, Kalyoncu U, Karadag O, et al. Effects of anti-tumor necrosis factor agents for familial mediterranean fever patients with chronic arthritis and/or sacroiliitis who were resistant to colchicine treatment. J Clin Rheumatol 2011;17:358-62.

38. Ortancil O, Sanlı A, Sapmaz Bulmuş P, Sarikaya S. A case with familial Mediterranean fever which responds well to adalimumab treatment. Turk J Rheumatol 2011;26:158-62. 